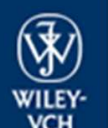

Advanced Synthesis \& Catalysis

\title{
Cobalt-Impregnated Magnetite as General Heterogeneous Catalyst for the Hydroacylation Reaction of Azodicarboxylates
}

\begin{tabular}{|r|l|}
\hline Journal: & Advanced Synthesis \& Catalysis \\
\hline Manuscript ID: & adsc. 201400207.R2 \\
\hline Wiley - Manuscript type: & Full Paper \\
\hline Date Submitted by the Author: & n/a \\
\hline Komplete List of Authors: & $\begin{array}{l}\text { Ramon, Diego J.; Universidad de Alicante, Quimica Organica } \\
\text { Pérez, Juana; Universidad de Alicante, Departamento de Química Orgánica }\end{array}$ \\
\hline \multicolumn{2}{|c|}{} \\
\hline $\begin{array}{l}\text { Note: The following files were submitted by the author for peer review, but cannot be converted to } \\
\text { PDF. You must view these files (e.g. movies) online. }\end{array}$ \\
\hline second Graphic files.zip
\end{tabular}

SCHOLARONE ${ }^{\text {m }}$

Manuscripts 


\title{
Cobalt-Impregnated Magnetite as General Heterogeneous Catalyst for the Hydroacylation Reaction of Azodicarboxylates
}

\author{
Juana M. Pérez ${ }^{\mathrm{a}}$, Diego J. Ramón ${ }^{\mathrm{a}}$ * \\ a Instituto de Síntesis Orgánica (ISO), and Departamento de Química Orgánica, Facultad de Ciencias, Universidad de \\ Alicante, Apdo. 99, E-03080-Alicante, Spain ${ }^{\text {a }}$ \\ E-mail: djramon@ua.es
}

Received: ((will be filled in by the editorial staff))

Supporting information for this article is available on the WWW under http://dx.doi.org/10.1002/adsc.201\#\#\#\#\#\#.((Please delete if not appropriate))

\begin{abstract}
Cobalt and nickel impregnated on magnetite The cobalt catalyst is stable enough to be removed by a catalysts have been prepared, characterized and used for the magnetic decantation and recycled ten-fold without hydroacylation reaction of different azodicarboxylate detrimental effect on the results. compounds with aldehydes, using nearly stoichiometric amounts of both reagents in only $3 \mathrm{~h}$. Furthermore, this Keywords: Aldehydes, Azo compounds, Cobalt, reaction has been conducted with the smallest amount of Heterogeneous catalysis catalyst.
\end{abstract}

\section{Introduction}

The C-N bond formation is one of the most important reactions in organic synthesis, which has found a wide application in the synthesis of many organic substances including natural products. ${ }^{[1]}$ This type of bonds has been constructed using polar, radical and transition metal-catalyzed reactions, ${ }^{[2]}$ with dialkyl azodicarboxylate compounds being used during the last few decades to perform this type of transformation. These reagents contain a vacant orbital and a strong electron-withdrawing group which contributes to make them good nucleophilic acceptors, favouring their reaction. Several types of reactions, such as the zwitterion intermediate reaction, the electrophilic $\alpha$-amination of carbonyl compounds, the $\mathrm{C}-\mathrm{H}$ activation at the $\alpha$-position of amines and ethers, and the ene-type reaction with olefins have been extensively studied using azodicarboxylate compounds. ${ }^{[3]}$ However, the hydroacylation reaction with aldehydes has been less considered. ${ }^{[4]}$

The first example of the hydroacylation of azodicarboxylate derivatives using an excess of formaldehyde ${ }^{[5]}$ was introduced in 1914 and after that, the scope of the aliphatic aldehydes for the reaction was increased, affording in all cases moderate yields after several days of reaction time. ${ }^{[6]}$ Recently, the use of unusual solvents, such as ionic liquids ${ }^{[7]}$ or water ${ }^{[8]}$ has been introduced in order to increase the reaction scope as well as to overcome other previous drawbacks. However, the reaction using arenecarbaldehydes still is very challenging and unsuccessful.
The first metal catalyzed process was introduced in 2004 using $\left[\mathrm{Rh}(\mathrm{OAc})_{2}\right]_{2} \quad(2 \mathrm{~mol} \%)$, with the aforementioned arenecarbaldehyde limitation not being overcome ${ }^{[9]}$ The use of copper(II) acetate, ${ }^{[10]}$ as well as zinc ${ }^{[11]}$ catalyst, allowed to carry out the reaction with aliphatic and aromatic aldehydes with similar yields for both substrates, but increasing the reaction time from $10 \mathrm{~h}$ for aliphatic aldehydes to several days for arenecarbaldehydes. It should be pointed out that there is only one example of heterogeneous catalyst performing the hydroacylation of azodicarboxylate derivatives. ${ }^{[12]}$ The reaction using $\mathrm{CuO}$ nanoparticles supported on silica $(10 \mathrm{~mol} \%)$, as catalyst, gave similar results, in terms of yields and reaction times $(12-30 \mathrm{~h})$ independently on the nature of aldehyde.

We have recently developed a new, simple and robust method to immobilize different metal oxides $^{[13]}$ on the surface of the magnetite. ${ }^{[14]}$ Here we show the application of this new cobalt catalyst ${ }^{[15]}$ for the hydroacylation reaction of azodicarboxylates compounds.

\section{Results and Discussion}

The hydroacylation reaction of diisopropyl azodicarboxylate (DIAD, 1a) and benzaldehyde (2a) catalyzed by iridium impregnated on magnetite was selected as the model for the optimization of the reaction conditions (Table 1). Benzaldehyde was chosen for its limited success in previous protocols, and the iridium catalyst for its tendency to have an easy electronic state change. Initially, the effect of 
temperature on the results was examined (entries 1-6), achieving the best result at $60{ }^{\circ} \mathrm{C}$ (entry 4). Then, different solvents were tested (entries 4 and 7-15), with the reaction proceeding with similar results in water and dichloroethane and reaching the best results in trichloroethylene. It should be pointed out that the hydrazine byproduct (4a) was obtained as the main compound in THF. In order to establish the hydrogen-donor for the process, the reaction was repeated using tetrahydrofuran- $\mathrm{d}_{8}$. After quenching the reaction by addition of toluene and magnetic decantation, the GC-MS of crude mixture showed the corresponding deuterated by-product $\mathbf{4 a}$, with the incorporation of the second deuterium being lower than $25 \%$. Then, the reaction was conducted with $\alpha$ deuterobenzaldehyde and THF, with the monoincorporation of deuterium to the byproduct $4 \mathbf{a}$ being negligible.

Table 1. Optimization of the Reaction Conditions ${ }^{\text {a) }}$

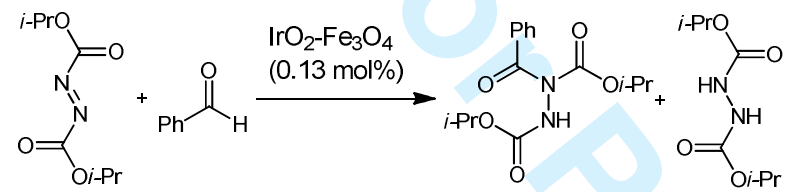

achieving surprisingly the best result with the cobalt catalyst in only $3 \mathrm{~h}$ (entry 4 ). To the best of our knowledge, this is the first time that a cobalt catalyst showed its great activity for the hydroacylation reaction. This reaction time is the shortest time ever reported for this type of reaction. The molecular oxygen seems to have an important role in the initial radical acyl formation in non-catalyzed processes. ${ }^{[8 c]}$ In order to clarified this aspect, the reaction was repeated but in inert atmosphere, obtaining similar result (entry 4, footnote d). Then, the reaction was carried out with different bimetallic catalysts (entries 19 and 20), obtaining worse results. Different amounts of catalyst were tested (entries 5, 6, 8 and 9) finding that increasing the amount of nickel or cobalt, the amount of byproduct $\mathbf{4 a}$ was increased, whereas the decrease of the catalyst amount, decreased the yield of $\mathbf{3 a}$.

Table 2. Optimization of the Catalyst ${ }^{\text {a) }}$

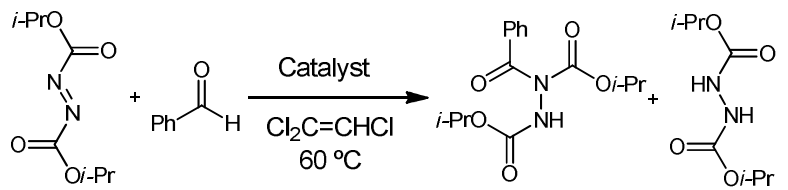

$1 a \quad 2 a \quad 3 a$

\begin{tabular}{|c|c|c|c|c|}
\hline Entry & Catalyst (mol\%) & $\begin{array}{l}\mathrm{t} \\
\text { (h) }\end{array}$ & $\begin{array}{l}\text { Yield 3a } \\
(\%)^{b)}\end{array}$ & $\begin{array}{l}\text { Yield 4a } \\
(\%)^{b)}\end{array}$ \\
\hline 1 & - & 5 & 42 & 7 \\
\hline 2 & $\mathrm{Fe}_{3} \mathrm{O}_{4}(21.6)$ & 3 & 45 & 7 \\
\hline 3 & $\left.\mathrm{Fe}_{3} \mathrm{O}_{4}(21.6)^{\mathrm{c}}\right)$ & 3 & 52 & 8 \\
\hline 4 & $\mathrm{CoO}-\mathrm{Fe}_{3} \mathrm{O}_{4}(1.42)$ & 3 & $90(93)^{d)}$ & 6 \\
\hline 5 & $\mathrm{CoO}-\mathrm{Fe}_{3} \mathrm{O}_{4}(2.8)$ & 3 & 78 & 18 \\
\hline 6 & $\mathrm{CoO}-\mathrm{Fe}_{3} \mathrm{O}_{4}(0.28)$ & 3 & 60 & 8 \\
\hline 7 & $\mathrm{NiO}-\mathrm{Fe}_{3} \mathrm{O}_{4}(1.03)$ & 3 & 83 & 6 \\
\hline 8 & $\mathrm{NiO}-\mathrm{Fe}_{3} \mathrm{O}_{4}(2.06)$ & 3 & 70 & 27 \\
\hline 9 & $\mathrm{NiO}-\mathrm{Fe}_{3} \mathrm{O}_{4}(0.21)$ & 3 & 66 & 6 \\
\hline 10 & $\mathrm{CuO}-\mathrm{Fe}_{3} \mathrm{O}_{4}(0.91)$ & 3 & 40 & 10 \\
\hline 11 & $\mathrm{Ru}_{2} \mathrm{O}_{3}-\mathrm{Fe}_{3} \mathrm{O}_{4}(1.03)$ & 3 & 51 & 7 \\
\hline 12 & $\mathrm{Rh}_{2} \mathrm{O}_{3}-\mathrm{Fe}_{3} \mathrm{O}_{4}(0.42)$ & 3 & 50 & 7 \\
\hline 13 & $\mathrm{PdO}-\mathrm{Fe}_{3} \mathrm{O}_{4}(1.22)$ & 3 & 69 & 8 \\
\hline 14 & $\begin{array}{l}\mathrm{Ag}_{2} \mathrm{O} / \mathrm{Ag}- \\
\mathrm{Fe}_{3} \mathrm{O}_{4}(1.25)\end{array}$ & 3 & 49 & 8 \\
\hline 15 & $\mathrm{WO}_{\mathrm{x}}-\mathrm{Fe}_{3} \mathrm{O}_{4}(0.57)$ & 3 & 51 & 7 \\
\hline 16 & $\mathrm{OsO}-\mathrm{Fe}_{3} \mathrm{O}_{4}(0.51)$ & 3 & 38 & 9 \\
\hline 17 & $\begin{array}{l}\mathrm{PtO} / \mathrm{PtO}_{2^{-}} \\
\mathrm{Fe}_{3} \mathrm{O}_{4}(0.54)\end{array}$ & 3 & 49 & 8 \\
\hline 18 & $\begin{array}{l}\mathrm{Au}_{2} \mathrm{O}_{3} / \mathrm{Au}- \\
\mathrm{Fe}_{3} \mathrm{O}_{4}(0.14)\end{array}$ & 3 & 43 & 9 \\
\hline 19 & $\begin{array}{l}\mathrm{NiO} / \mathrm{Cu}- \\
\mathrm{Fe}_{3} \mathrm{O}_{4}(0.91 / 0.88)\end{array}$ & 3 & 43 & 12 \\
\hline 20 & $\begin{array}{l}\mathrm{PdO} / \mathrm{Cu}- \\
\mathrm{Fe}_{3} \mathrm{O}_{4}(1.53 / 0.90)\end{array}$ & 3 & 4 & 11 \\
\hline 21 & $\mathrm{CoO}(1.42)$ & 3 & 46 & 9 \\
\hline 22 & $\mathrm{NiO}(1.03)$ & 3 & 46 & 8 \\
\hline
\end{tabular}

a) Reaction carried out using compounds 1a (1mmol) and 2a $(1.2 \mathrm{mmol})$ and $1 \mathrm{~mL}$ of solvent. ${ }^{\text {b) }}$ Isolated yield after column chromatography. ${ }^{c}$ Reaction performed with nanoparticulate magnetite $(<50 \mathrm{~nm}) \cdot{ }^{\mathrm{d})}$ Reaction performed in argon atmosphere. 
Reactions using cobalt oxide or nickel oxide alone gave moderate yields (entries 21 and 22), with these results pointing out the high activity of these nanostructured catalysts. It should be highlighted that the optimal amount of catalyst is the lowest one ever reported.

Having established the similar catalytic activity for cobalt and nickel derivatives, the problem of recycling was faced (Figure 1). When the catalyst was recovered from the reaction mixture by magnetic decantation, washed with toluene, and reused under the same reaction conditions, the expected product $\mathbf{3 a}$ was obtained in good yields with both catalysts. These catalysts could be recycled up to 10 times with a slight loss of their activity for the case of $\mathrm{NiO}$ $\mathrm{Fe}_{3} \mathrm{O}_{4}$, in which the yield decreased to $53 \%$. However, the $\mathrm{CoO}-\mathrm{Fe}_{3} \mathrm{O}_{4}$ catalyst kept its activity practically constant and only in the last reaction cycle the yield decreased slightly.

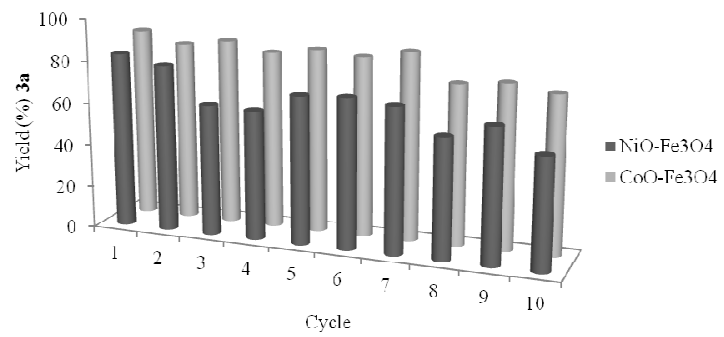

Figure 1. Recycling of the $\mathrm{NiO}-\mathrm{Fe}_{3} \mathrm{O}_{4}$ and $\mathrm{CoO}-\mathrm{Fe}_{3} \mathrm{O}_{4}$ catalyst.

In order to study the effect of the reaction conditions on the cobalt catalyst, the nanosize distribution of the cobalt catalyst was measured after only one reaction process, and after ten-times, observing a small sinterization of the nanoparticles. Before the reaction, the size of $77 \%$ of the cobalt oxide particles on the surface of the catalyst was between 1 and $4 \mathrm{~nm}$. After the first recycling of the catalyst, the average of the cobalt oxide particles was practically the same, as the fresh one. However, after ten reactions, the recycled catalyst suffered a small sinterization process, with the $73 \%$ of cobalt oxide particles measuring between 2 and $6 \mathrm{~nm}$ (Figure 2).

The XPS study of catalyst ${ }^{[16]}$ showed the transformation of cobalt(II) oxide onto the corresponding cobalt(II) hydroxide. These small changes in particle size as well as the initial cobalt species seemed not to affect the activity of the catalyst, since it could be reused ten times with similar results. To know if the reaction took place by the leached cobalt species to the organic medium, we performed the standard reaction (Table 3, entry 1). After that, the catalyst was removed carefully by a magnet at high temperature, and washed with trichloroethylene. The solvents of the above solution, without catalyst, were removed under low pressure and DIAD (1a) and 3-methylbenzaldehyde, as well as $1 \mathrm{~mL}$ of $\mathrm{Cl}_{2} \mathrm{CCHCl}$, were added to the above residue. The resulting solution was heated again at $60{ }^{\circ} \mathrm{C}$ for 3 $\mathrm{h}$. The analysis of crude mixture, after hydrolysis, revealed the formation of compound $\mathbf{3 a}$ in $93 \%$ (catalyzed process) and product 3c in $72 \%$ yield by GC-analysis (compare with entry 3 in Table 3). It seems that the reaction takes places under homogeneous conditions. Finally ICP-MS analysis of the crude reaction solution showed the leaching of a small amount of cobalt ( $1.4 \%$ of the initial amount) and iron $(0.17 \%$ of the initial amount).

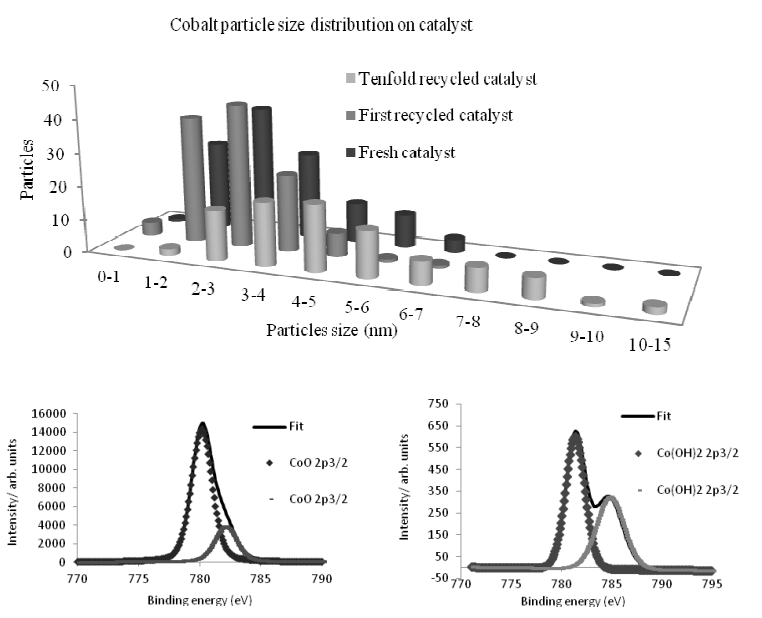

Figure 2. a) Cobalt particle size distribution on catalyst. b) XPS of cobalt catalyst before reaction. c) XPS of cobalt catalyst after ten reactions.

All these data seem to point into the direction that the initial cobalt-impregnated magnetite catalyst is only a reservoir for homogeneous cobalt species, and after the reaction has taken place in the homogeneous solvent phase, the cobalt species is efficiently re-adsorbed by the magnetite surface, keeping its activity.

The evolution of yield for compound $\mathbf{3 a}$ with the time at different catalyst and reactive loadings is depicted in Figure 3. Assuming that the equation rate is simple and that the reaction conditions permit a pseudo-first order approximation for all reagents, the equation rate could be expressed as $\operatorname{Ln} r_{o i}=\alpha \operatorname{Ln}[A]_{o i}$ + constant, being [A] the initial concentration of catalyst or reagents. The estimation of the initial reaction rate for each trial and their representation allowed us to estimate the value of the reaction order for the catalyst and for both reagents, with the obtained value being very close to $1 / 2$ for both reagents and $3 / 4$ for cobalt catalyst. These results pointed out that the mechanism is not very simple and 
could be an indirect indication of a previously reported radical mechanism. To verify this fact, a radical scavenger (TEMPO) was added to the initial reaction solution, recovering the starting reagents unchanged after $6 \mathrm{~h}$. In order to know if the sun light had some impact on the possible radical reaction pathway, the reaction was performed in a light protected tube, affording a similar result $(88 \%)$ to that presented in Table 2, entry 4.
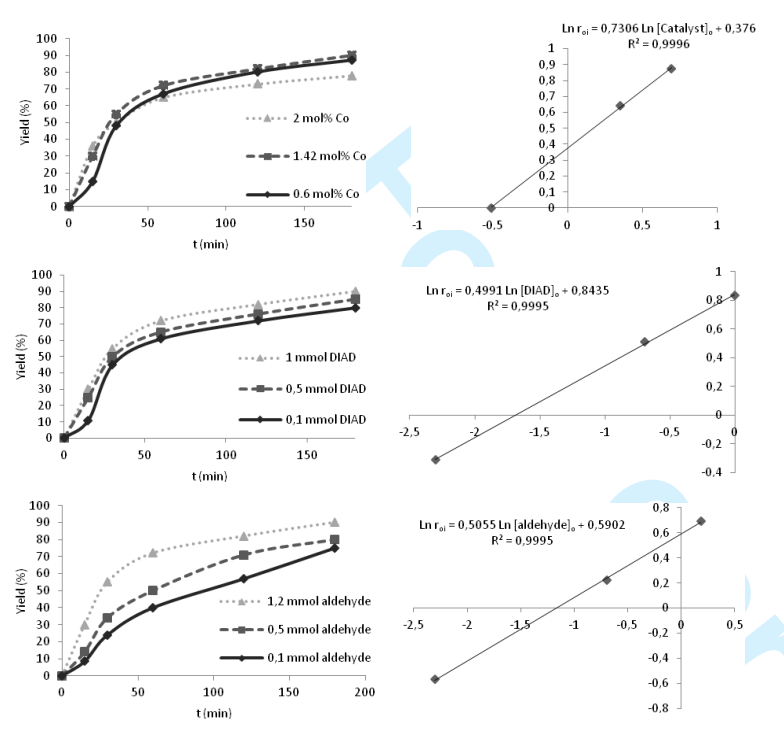

Figure 3. Plot-time yield, and correlation between initial rates and the corresponding catalyst and reagents.

With the best conditions in hand, the scope of the reaction was evaluated using cobalt as well as nickel catalyst (Table 3 ). The reaction gave excellent and consistent results when diisopropyl azodicarboxylate reagent was employed using different arenecarbaldehydes bearing electron withdrawing groups (Table 3, entries 7-10). However, the presence of electron donating groups at the aryl moiety decreased somehow the yield, with the reaction using 3,4,5-trimethoxybenzaldehyde giving the worse result (entry 6). Interestingly, the reaction using cobalt catalyst led to higher yields than by using nickel. The reaction reached good results when other aromatic aldehydes, including heteroaromatic (entry 12) or $\alpha, \beta$-unsaturated aldehydes (entry 13 ), were used. The reaction with aliphatic aldehydes also gave excellent results independently of the substitution at the $\alpha$ position or the presence of an isolated $\mathrm{C}-\mathrm{C}$ double bond. It should be pointed out that the reaction using diethyl azodicarboxylate gave practically the same result as the diisopropyl derivative. However, when the steric hindrance of the azoderivative was increased the final yield decreased (compare entries 1, 19 and 20).
Table 3. Preparation of hydroacylation products ${ }^{\mathrm{a})}$

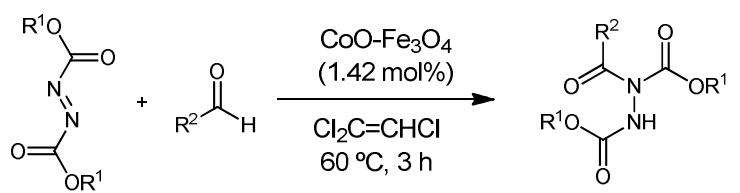

12

\begin{tabular}{|c|c|c|c|c|}
\hline Ent & $\mathrm{R}^{1}$ & $\mathrm{R}^{2}$ & No & $\begin{array}{l}\text { Yield } \\
(\%)^{b)}\end{array}$ \\
\hline 1 & $i$-Pr & $\mathrm{Ph}$ & $3 \mathbf{a}$ & $\left.89(83)^{c}\right)$ \\
\hline 2 & $i$-Pr & 2- $\mathrm{MeC}_{6} \mathrm{H}_{4}$ & $\mathbf{3 b}$ & $\left.86(75)^{c}\right)$ \\
\hline 3 & $i-\operatorname{Pr}$ & $3-\mathrm{MeC}_{6} \mathrm{H}_{4}$ & $3 c$ & $79(99)^{c)}$ \\
\hline 4 & $i$-Pr & 4- $\mathrm{MeC}_{6} \mathrm{H}_{4}$ & 3d & $\left.72(78)^{c}\right)$ \\
\hline 5 & $i$-Pr & $4-\mathrm{MeOC}_{6} \mathrm{H}_{4}$ & $3 e$ & $67(41)^{c)}$ \\
\hline 6 & $i-\operatorname{Pr}$ & $3,4,5-(\mathrm{MeO})_{3} \mathrm{C}_{6} \mathrm{H}_{2}$ & $3 f$ & $\left.26(8)^{c}\right)$ \\
\hline 7 & $i-\operatorname{Pr}$ & $4-\mathrm{FC}_{6} \mathrm{H}_{4}$ & $3 g$ & $90(86)^{c}$ \\
\hline 8 & $i$-Pr & $2-\mathrm{ClC}_{6} \mathrm{H}_{4}$ & $3 \mathbf{h}$ & $95(38)^{\mathrm{c})}$ \\
\hline 9 & $i-\operatorname{Pr}$ & $3-\mathrm{ClC}_{6} \mathrm{H}_{4}$ & $3 \mathbf{i}$ & $97(88)^{c}$ \\
\hline 10 & $i-\operatorname{Pr}$ & 4- $\mathrm{ClC}_{6} \mathrm{H}_{4}$ & $\mathbf{3 j}$ & $\left.87(65)^{c}\right)$ \\
\hline 11 & $i$-Pr & 1-naphthyl & $\mathbf{3 k}$ & $87(79)^{c}$ \\
\hline 12 & $i-\operatorname{Pr}$ & 1-thienyl & 31 & $\left.60(60)^{c}\right)$ \\
\hline 13 & $i-\operatorname{Pr}$ & $\mathrm{C}_{6} \mathrm{H}_{5} \mathrm{CH}=\mathrm{CH}$ & $3 m$ & $74(82)^{c)}$ \\
\hline $14^{\mathrm{d}}$ & $i$-Pr & $\mathrm{CH}_{3}\left(\mathrm{CH}_{2}\right)_{2}$ & $3 n$ & 99 \\
\hline $15^{\mathrm{d}}$ & $i-\operatorname{Pr}$ & $\mathrm{CH}_{3}\left(\mathrm{CH}_{2}\right)_{7}$ & 30 & 99 \\
\hline $16^{\mathrm{d}}$ & $i$-Pr & $\left(\mathrm{CH}_{3} \mathrm{CH}_{2}\right)_{2} \mathrm{CH}$ & $3 \mathbf{p}$ & $\left.99(99)^{c}\right)$ \\
\hline $17^{\mathrm{d}}$ & $i$-Pr & $\left(\mathrm{CH}_{3}\right)_{3} \mathrm{C}$ & $3 \mathbf{q}$ & $\left.75(88)^{c}\right)$ \\
\hline 18 & $i$-Pr & $(Z)-\mathrm{EtCH}=\mathrm{CH}\left(\mathrm{CH}_{2}\right)_{5}$ & $3 \mathbf{r}$ & 99 \\
\hline 19 & Et & $\mathrm{Ph}$ & $3 s$ & $99(99)^{\mathrm{c})}$ \\
\hline 20 & $t-\mathrm{Bu}$ & $\mathrm{Ph}$ & $3 t$ & $\left.40(62)^{c}\right)$ \\
\hline
\end{tabular}

a) Reaction carried out using compounds $\mathbf{1}(1 \mathrm{mmol})$ and $\mathbf{2}$ $(1.2 \mathrm{mmol})$ and $1 \mathrm{~mL}$ of solvent. ${ }^{\text {b) }}$ Isolated yield after column chromatography. ${ }^{\text {c }}$ Reaction carried out with NiO$\mathrm{Fe}_{3} \mathrm{O}_{4}(1.03 \mathrm{~mol} \%)$ catalyst. ${ }^{\text {d) }}$ Reaction carried out during $30 \mathrm{~min}$.

\section{Conclusion}

In conclusion, we have demonstrated that cobalt impregnated on magnetite is a good catalyst for the hydroacylation reaction with azodicarboxylates independently of the nature of aldehyde and using nearly stoichiometric amounts of both reagents, with the nickel catalyst having similar activity. Furthermore, this reaction could be conducted with the smallest amount of catalyst, requiring the shortest reaction time, compared to previous results in the literature. The catalyst was stable enough to be removed by a magnetic decantation and recycled tenfold with any detrimental effect on the results.

\section{Experimental Section}

General Information. Melting points were obtained with a Reichert Thermovar apparatus. NMR spectra were recorded on a Bruker $\mathrm{AC}-300\left(300 \mathrm{MHz}\right.$ for ${ }^{1} \mathrm{H}$ and 75 $\mathrm{MHz}$ for ${ }^{13} \mathrm{C}$ ) using $\mathrm{CDCl}_{33_{3}}$ as a solvent and TMS as internal standard for ${ }^{1} \mathrm{H}$ and ${ }^{13} \mathrm{C}$; chemical shifts are given 
in $\delta$ (parts per million) and coupling constants $(J)$ in Hertz. FT-IR spectra were obtained on Jasco 4100 LE (Pike Miracle ATR) spectrophotometer. Mass spectra (EI) were obtained at $70 \mathrm{eV}$ on a Himazdu QP-5000 spectrometer, giving fragment ions in $\mathrm{m} / \mathrm{z}$ with relative intensities $(\%)$ in parentheses. Thin layer chromatography (TLC) was carried out on Schleicher \& Schuell F1400/LS 254 plates coated with a $0.2 \mathrm{~mm}$ layer of silica gel; detection by $\mathrm{UV}_{254}$ light, staining with phosphomolybdic acid $[25 \mathrm{~g}$ concentrated $\mathrm{H}_{2} \mathrm{SO}_{4}$ and $940 \mathrm{~mL}_{2} \mathrm{O}$. Column chromatography was performed using silica gel 60 of 40 $63 \mathrm{mesh}$. All reagents were commercially available (Acros, Aldrich, Fluorochem) and were used as received. The Xray Fluorescence analyses were carried out on a PHILIPS MAGIX PRO (PW2400) X-ray spectrometer equipped with a rhodium X-ray tube and a beryllium window. The incorporation of cobalt was determined by X-ray fluorescence. The BET analyses were carried out on a automatic volumetric AUTOSORB-6 Quantachrome and its degasser unit. $\mathrm{N}_{2}$ at $77 \mathrm{~K}$ was used as gas. X-ray photoelectron spectroscopy analyses were carried out on a VG-Microptech Multilab 3000 equipped with a hemispheric electron analyzer with 9 channeltrons (pass energy between 2 and $200 \mathrm{eV}$ ) and a X-ray tube with $\mathrm{Mg}$ and Al anodes. TEM analyses were carried out on a JEOL JEM-2010 microscope, equipped with a X-ray detector Oxford Inca Energy TEM 100 for microanalysis (EDS). The program Fiji-win32 was used to measure the particle size distribution on TEM images. XRD analyses were obtained on a Bruker D-8 advance diffractometer cith Göebel mirror with high temperature chamber and X-ray generator Kristalloflex K $760-80 \mathrm{~F}(3 \mathrm{KW}, 20-60 \mathrm{KV}$ and 5$80 \mathrm{~mA}$ ).

General Procedure for the Preparation of Cobalt Catalyst. To a stirred solution of the metal salt $\mathrm{CoCl}_{2} \cdot 6 \mathrm{H}_{2} \mathrm{O}(1 \mathrm{mmol}, 238 \mathrm{mg})$ or $\mathrm{NiCl}_{2} \cdot \mathrm{H}_{2} \mathrm{O}(1 \mathrm{mmol}$, $130 \mathrm{mg})$ in deionized water $(120 \mathrm{~mL})$ was added commercial available $\mathrm{Fe}_{3} \mathrm{O}_{4}(4 \mathrm{~g}, 17 \mathrm{mmol}$, powder $<5 \mu \mathrm{m}$, BET area: $9.86 \mathrm{~m}^{2} / \mathrm{g}$ ). After 10 minutes at room temperature, the mixture was slowly basified with $\mathrm{NaOH}$ (1M) until $\mathrm{pH}$ around 13. The mixture was stirred during one day at room temperature in air. After that, the catalyst was filtered and washed several times with deionized water $(3 \times 10 \mathrm{~mL})$. The solid was dried at $100{ }^{\circ} \mathrm{C}$ during $24 \mathrm{~h}$ in a standard glassware oven, obtaining the expected catalyst.

General Procedure for the Hydroacylation of Azodicarboxylate Compounds. To a stirred solution of the corresponding aldehyde $(2,1.2 \mathrm{mmol})$ in trichloroethylene $(1 \mathrm{~mL})$ were added the catalyst $(50 \mathrm{mg})$ and the corresponding substituted azodicarboxylate $(\mathbf{1}, 1$ $\mathrm{mmol}$ ). The resulting mixture was stirred at $60{ }^{\circ} \mathrm{C}$ until the end of the reaction. The catalyst was removed by a magnet and the resulting mixture was quenched with water and extracted with AcOEt $(3 \times 5 \mathrm{~mL})$. The organic phases were dried over $\mathrm{MgSO}_{4}$, followed by evaporation under reduced pressure to remove the solvent. The product was usually purified by chromatography on silica gel (hexane/ethyl acetate) to give the corresponding products 3. Physical and spectroscopic data, as well as literature for known compounds, follow.

Diisopropyl 1-benzoylhydrazine-1,2-dicarboxylate (3a): ${ }^{[2]}$ White solid; $\mathrm{mp}=120-121{ }^{\circ} \mathrm{C}$ (hexane); $\mathrm{t}_{\mathrm{r}}=15.8$; $\mathrm{R}_{\mathrm{f}}=0.1$ (hexane/ehtyl acetate: 4/1); $\mathrm{H}$ NMR (300 MHz, $\left.\mathrm{CDCl}_{3}\right): \delta 7.69(\mathrm{~m}, 2 \mathrm{H}), 7.52(\mathrm{t}, J=7.4 \mathrm{~Hz}, 1 \mathrm{H}), 7.4-7.45$ $(\mathrm{m}, 2 \mathrm{H}), 6.87(\mathrm{~s}, \mathrm{br}, 1 \mathrm{H}), 4.85-5.1(2 \mathrm{~m}, 1$ and $1 \mathrm{H}$, respectively), $1.30(\mathrm{~d}, J=6.0 \mathrm{~Hz}, 6 \mathrm{H}), 1.07(\mathrm{~d}, J=5.4 \mathrm{~Hz}$, $6 \mathrm{H}) ;{ }^{13} \mathrm{C} \mathrm{NMR}\left(75 \mathrm{MHz}^{\mathrm{CDCl}} \mathrm{CDC}_{3}: \delta 171.1,155.2,152.8\right.$ 135.1, 131.8, 128.0 (4C), 72.3, 70.5, 21.8 (2C), 21.2 (2C). IR (ATR): v 3275, 1756, 1740, 1684, 1251, $1047 \mathrm{~cm}^{-1}$; MS (EI) $m / z(\%): 222(8), 105(100), 77$ (17).

Diisopropyl

1-(2-methylbenzoyl)hydrazine-1,2dicarboxylate (3b): Pale yellow solid; $\mathrm{mp}=64-66{ }^{\circ} \mathrm{C}$ (hexane); $\mathrm{t}_{\mathrm{r}}=15.9 ; \mathrm{R}_{\mathrm{f}}=0.53$ (hexane/ethyl acetate: $3 / 2$ ); ${ }^{2} \mathrm{H}$ NMR (300 MHz, CDCl $\left.{ }_{3}\right): \delta$ 7.3-7.4 (m, 2H), 7.15-7.3 $(\mathrm{m}, 2 \mathrm{H}), 6.97(\mathrm{~s}, \mathrm{br}, 1 \mathrm{H}), 5.03$ (heptet, $J=6.2 \mathrm{~Hz}, 1 \mathrm{H})$, 4.84 (heptet, $J=6.2 \mathrm{~Hz}, 1 \mathrm{H}), 2.39(\mathrm{~s}, 3 \mathrm{H}), 1.3(\mathrm{~d}, J=6.2$ $\mathrm{Hz}, 6 \mathrm{H}), 1.0(\mathrm{~d}, J=6.2 \mathrm{~Hz}, 6 \mathrm{H}) ;{ }^{13} \mathrm{C}$ NMR $(75 \mathrm{MHz}$, $\left.\mathrm{CDCl}_{3}\right)$ : $\delta$ 170.4, 155.1, 152.2, 136.1, 135.2, 130.2, 129.9, $126.2,125.3,72.3,70.6,21.9$ (2C), 21.1 (2C), 9.1; IR (ATR): v 3294, 2984, 1754, 1734, 1687, 1252, $1505 \mathrm{~cm}^{-1}$; MS (EI) $m / z(\%): 322\left(\mathrm{M}^{+}, 0.1\right), 120$ (9), 119 (100), 91 (17); Elemental analysis calcd. for $\mathrm{C}_{16} \mathrm{H}_{22} \mathrm{~N}_{2} \mathrm{O}_{5}$ : $\mathrm{C}=59.61$, $\mathrm{H}=6.88, \mathrm{~N}=8.69$; found: $\mathrm{C}=59.65, \mathrm{H}=6.93, \mathrm{~N}=8.59$.

Diisopropyl 1-(3-methylbenzoyl)hydrazine-1,2dicarboxylate (3c): White solid; $\mathrm{mp}=96-98^{\circ} \mathrm{C}$ (hexane); $\mathrm{t}_{\mathrm{r}}=16.3 ; \mathrm{R}_{\mathrm{f}}=0.7$ (hexane/ethyl acetate: $3 / 2$ ); ${ }^{2} \mathrm{H}$ NMR (300 MHz, CDCl $): \delta 7.5(\mathrm{~m}, 2 \mathrm{H}), 7.25-7.35(\mathrm{~m}, 2 \mathrm{H}), 6.96$ (s, br, 1H), 5.01 (heptet, $J=6.2 \mathrm{~Hz}, 1 \mathrm{H}$ ), 4.89 (heptet, $J=$ $6.2 \mathrm{~Hz}, 1 \mathrm{H}), 2.38(\mathrm{~s}, 3 \mathrm{H}), 1.29(\mathrm{~d}, J=6.2 \mathrm{~Hz}, 6 \mathrm{H}), 1.07$ (d, $J=6.2 \mathrm{~Hz}, 6 \mathrm{H}) ;{ }^{13} \mathrm{C}$ NMR $\left(75 \mathrm{MHz}^{2} \mathrm{CDCl}_{3}\right): \delta 171.3$, $155.2,152.9,137.9,135.1,132.6,128.9,128.0,125.2,72.3$, 70.6, 21.9 (2C), 21.3 (2C), 21.2; IR (ATR): v 3273, 2985, 1741, 1689, 1519, 1252; MS (EI) $m / z$ (\%): $236(8), 120$ (9), 119 (100), 91 (18) cm cm $^{-1}$; Elemental analysis calcd. for $\mathrm{C}_{16} \mathrm{H}_{22} \mathrm{~N}_{2} \mathrm{O}_{5}: \mathrm{C}=59.61, \stackrel{\mathrm{H}}{=}=6.88, \mathrm{~N}=8.69$; found: $\mathrm{C}=$ $59.68, \mathrm{H}=7.01, \mathrm{~N}=8.75$.

Diisopropyl 1-(p-tolyl)hydrazine-1,2-dicarboxylate (3d): ${ }^{[12]}$ White solid; $\mathrm{mp}=100-102{ }^{\circ} \mathrm{C}$ (hexane); $\mathrm{t}_{\mathrm{r}}=16.4$; $\mathrm{R}_{\mathrm{f}}=0.7$ (hexane/ethyl acetate: $3 / 2$ ); $\mathrm{H}$ NMR $(300 \mathrm{MHz}$, $\left.\mathrm{CDCl}_{3}\right): \delta 7.61(\mathrm{~m}, 2 \mathrm{H}), 7.22(\mathrm{~d}, J=7.9 \mathrm{~Hz}, 2 \mathrm{H}), 6.86(\mathrm{~s}$, br, $1 \mathrm{H}), 4.9-5.1(2 \mathrm{~m}, 1$ and $1 \mathrm{H}$, respectively), $2.40(\mathrm{~s}, 3 \mathrm{H})$, $1.29(\mathrm{~d}, J=5.6 \mathrm{~Hz}, 6 \mathrm{H}), 1.11(\mathrm{~d}, J=5.6 \mathrm{~Hz}, 6 \mathrm{H}) ;{ }^{3} \mathrm{C}$ NMR $\left(75 \mathrm{MHz}, \mathrm{CDCl}_{3}\right): \delta 171.1,155.2,153.0,142.7$, 132.1, 128.7 (2C), 128.4 (2C), 72.3, 70.6, 21.9 (2C), 21.6, 21.3 (2C); IR (ATR): $v$ 3281, 1753, 1736, 1685, 1250, $1044 \mathrm{~cm}^{-1}$; MS (EI) $\mathrm{m} / z$ (\%): 236 (9), 120 (14), 119 (100), $91(22)$.

Diisopropyl 1-(4-methoxyphenyl)hydrazine-1,2dicarboxylate (3e) $:{ }^{[9 a]}$ White solid; mp $=85-87{ }^{\circ} \mathrm{C}$ (hexane); $\mathrm{t}_{\mathrm{r}}=17.4 ; \mathrm{R}_{\mathrm{f}}=0.57$ (hexane/ethyl acetate: $3 / 2$ ); ${ }^{\mathrm{H}}$ NMR $\left(300 \mathrm{MHz}, \mathrm{CDCl}_{3}\right): \delta 7.73(\mathrm{~m}, 2 \mathrm{H}), 7.05(\mathrm{~s}, \mathrm{br}$, $1 \mathrm{H}), 6.91(\mathrm{~d}, J=8.8 \mathrm{~Hz}, 2 \mathrm{H}), 4.85-5.05(\mathrm{~m}, 2 \mathrm{H}), 3.85$ ( $\mathrm{s}$, $3 \mathrm{H}), 1.28(\mathrm{~d}, J=6.0 \mathrm{~Hz}, 6 \mathrm{H}), 1.13(\mathrm{~d}, J=6.0 \mathrm{~Hz}, 6 \mathrm{H}) ;{ }^{13} \mathrm{C}$ NMR $\left(75 \mathrm{MHz}_{2} \mathrm{CDCl}_{3}\right): \delta 170.6,163.9,163.0,153.4$, $153.2,132.3,131.0,113.4(2 \mathrm{C}), 72.2,70.5,55.4,21.9(2 \mathrm{C})$, 21.4 (2C); IR (ATR): v 3258, 1748, 1719, 1698, 1251, $1024 \mathrm{~cm}^{-1}$; MS (EI) $\mathrm{m} / z(\%): 136$ (10), 135 (100).

Diisopropyl 1-(3,4,5-trimethoxybenzoyl)hydrazine-1,2dicarboxylate (3f): ${ }^{[12]}$ White solid; $\mathrm{mp}=92-94{ }^{\circ} \mathrm{C}$ (hexane); $\mathrm{t}_{\mathrm{r}}=18.9 ; \mathrm{R}_{\mathrm{f}}=0.3$ (hexane/ethyl acetate: $3 / 2$ ) $;{ }^{1} \mathrm{H}$

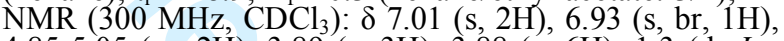
$4.85-5.05(\mathrm{~m}, 2 \mathrm{H}), 3.89(\mathrm{~s}, 3 \mathrm{H}), 3.88(\mathrm{~s}, 6 \mathrm{H}), 1.3(\mathrm{~d}, J=$ $6.3 \mathrm{~Hz}, 6 \mathrm{H}), 1.14(\mathrm{~d}, J=6.3 \mathrm{~Hz}, 6 \mathrm{H}) ;{ }^{13} \mathrm{C} \mathrm{NMR}(75 \mathrm{MHz}$, $\left.\mathrm{CDCl}_{3}\right): \delta 170.8,155.3,153.0,152.9$ (2C), 141.7, 129.9, 106.0 (2C), 72.4, 70.6, 60.9, 56.2 (2C), 21.9 (2C), 21.4 (2C); IR (ATR): v 3283, 2979, 1746, 1719, 1699, 1587, $1248 \mathrm{~cm}^{-1}$; MS (EI) $\mathrm{m} / z(\%): 398\left(\mathrm{M}^{+}, 5 \%\right), 196(11), 195$ (100).

Diisopropyl 1-(4-fluorobenzoyl)hydrazine-1,2dicarboxylate $(\mathbf{3 g}):^{[8 \mathrm{~b}]}$ White solid; $\mathrm{mp}=98-99{ }^{\circ} \mathrm{C}$ (hexane); $\mathrm{t}_{\mathrm{r}}=15.5 ; \mathrm{R}_{\mathrm{f}}=0.8$ (hexane/ethyl acetate: $\left.1 / 1\right) ;{ }^{1} \mathrm{H}$ NMR $\left(300 \mathrm{MHz}, \mathrm{CDCl}_{3}\right): \delta 1.14(\mathrm{~d}, J=5.9 \mathrm{~Hz}, 6 \mathrm{H}), 1.31$ $(\mathrm{d}, J=5.9 \mathrm{~Hz}, 6 \mathrm{H}), 4.9-5.05(\mathrm{~m}, 2 \mathrm{H}), 6.95-7.0(\mathrm{~m}, 1 \mathrm{H})$, $7.12(\mathrm{t}, J=7.1 \mathrm{~Hz}, 2 \mathrm{H}), 7.7-7.75(\mathrm{~m}, 2 \mathrm{H}) ;{ }^{13} \mathrm{C}$ NMR $(75$ $\left.\mathrm{MHz}, \mathrm{CDCl}_{3}\right): \delta 170.2,164.9\left(\mathrm{~d}, J_{\mathrm{C}-\mathrm{F}}=253.3 \mathrm{~Hz}, \mathrm{C}\right)$, $152.8,152.2,131.1,130.8\left(\mathrm{~d}, J_{\mathrm{C}-\mathrm{F}}=6.8 \mathrm{~Hz}, 2 \mathrm{C}\right), 115.3(\mathrm{~d}$, $\left.J_{\mathrm{C}-\mathrm{F}}=22 \mathrm{~Hz}, 2 \mathrm{C}\right), 72.6,70.7,21.9$ (2C), 21.4 (2C); IR (ATR): $v$ 3282, 1745, 1723, 1698, $1283 \mathrm{~cm}^{-1}:$ MS (EI) $\mathrm{m} / z$ (\%): 240 (10), 154 (10), 124 (12), 123 (100), 95 (20).

Diisopropyl 1-(2-chlorobenzoyl)hydrazine-1,2dicarboxylate $(3 \mathrm{~h})$ : Yellow oil; $\mathrm{t}_{\mathrm{r}}=16.4 ; \mathrm{R}_{\mathrm{f}}=0.63$ (hexane/ethyl acetate: $3 / 2) ;{ }^{1} \mathrm{H}$ NMR $\left(300 \mathrm{MHz}, \mathrm{CDCl}_{3}\right): \delta$ 7.3-7.5 (m, 4H), 6.99 (s,1H), 4.85-5.05 $(2 \mathrm{~m}, 1$ and $1 \mathrm{H}$, respectively), $1.05-1.35\left(2 \mathrm{~m}, 6\right.$ and $6 \mathrm{H}$, respectively); ${ }^{13} \mathrm{C}$ NMR (75 $\left.\mathrm{MHz}, \mathrm{CDCl}_{3}\right): \delta 167.5,154.9,151.6,136.1$, $130.8,130.2$, 129.3, 127.9, 126.6, 72.6, 70.6, 21.8 (2C), 
21.2 (2C); IR (ATR) v 3312, 2983, 2937, 1739, $1257 \mathrm{~cm}^{-1}$ MS (EI) $m / z(\%): 256$ (10), 141 (34), 139 (100), $111(12)$ Elemental analysis calcd. for $\mathrm{C}_{15} \mathrm{H}_{10} \mathrm{ClN}_{2} \mathrm{O}_{5}: \mathrm{C}=52.56, \mathrm{H}$ $=5.59, \mathrm{~N}=8.17$; found: $\mathrm{C}=52.42, \mathrm{H}=5.49, \mathrm{~N}=8.23$.

\section{Diisopropyl 1-(3-chlorobenzoyl)hydrazine-1,2-} dicarboxylate (3i): White solid; $\mathrm{mp}=108-110{ }^{\circ} \mathrm{C}$ (hexane); $\mathrm{t}_{\mathrm{r}}=16.5 ; \mathrm{R}_{\mathrm{f}}=0.7$ (hexane/ethyl acetate: $3 / 2$ ); ${ }^{1} \mathrm{H}$ NMR (300 MHz, $\left.\mathrm{CDCl}_{3}\right): \delta$ 7.45-7.65 (m, 3H), 7.3-7.4 (m, $1 \mathrm{H}), 7.04(\mathrm{~s}, \mathrm{br}, 1 \mathrm{H}), 4.9-5.1(\mathrm{~m}, 2 \mathrm{H}), 1.3(\mathrm{~d}, J=6.2 \mathrm{~Hz}$ $6 \mathrm{H}), 1.11(\mathrm{~d}, J=5.9 \mathrm{~Hz}, 6 \mathrm{H}) ;{ }^{3} \mathrm{C}$ NMR $\left(75 \mathrm{MHz}, \mathrm{CDCl}_{3}\right)$ : $\delta 169.8,155.1,152.5,136.8,134.2,131.7,129.5,128.0$, 126.1, 72.8, 70.8, 21.9 (2C), 21.3 (2C); IR (ATR): v 3286, $2985,2940,1744,1757,1527,1518,1254 \mathrm{~cm}^{-1}:$ MS (EI) $m / z$ (\%): 256 (12), 214 (11), 170 (17), 141 (39), 139 (100), 111 (20); Elemental analysis calcd. for $\mathrm{C}_{16} \mathrm{H}_{22} \mathrm{ClN}_{2} \mathrm{O}_{5}$ : C = $52.56, \mathrm{H}=5.59, \mathrm{~N}=8.17$; found: $\mathrm{C}=52.59, \mathrm{H}=5.48, \mathrm{~N}=$ 8.08 .

Diisopropyl 1-(4-chlorobenzoyl)hydrazine-1,2dicarboxylate $(\mathbf{3 j}):{ }^{[9 \mathrm{a}]}$ White solid; $\mathrm{mp}=82-84{ }^{\circ} \mathrm{C}$ (hexane); $\mathrm{t}_{\mathrm{r}}=16.6 ; \mathrm{R}_{\mathrm{f}}=0.7$ (hexane/ethyl acetate: $\left.3 / 2\right) ;{ }^{1} \mathrm{H}$ NMR (300 MHz, $\left.\mathrm{CDCl}_{3}\right): \delta$ 7.65-7.7 (m, 2H), 7.3-7.4" $(\mathrm{m}$, $2 \mathrm{H}), 6.95(\mathrm{~s}, \mathrm{br}, 1 \mathrm{H}), 4.9-5.05(\mathrm{~m}, 2 \mathrm{H}), 1.3(\mathrm{~d}, J=5.2 \mathrm{~Hz}$, $6 \mathrm{H}), 1.13(\mathrm{~d}, J=5.2 \mathrm{~Hz}, 6 \mathrm{H}) ;{ }^{13} \mathrm{C} \mathrm{NMR}\left(75 \mathrm{MHz}, \mathrm{CDCl}_{3}\right)$ : $\delta 170.2,155.1,152.7,138.2,133.4,129.6(2 \mathrm{C}), 128.4(2 \mathrm{C})$, 72.7, 70.8, 21.9 (2C), 21.4 (2C); IR (ATR): v 3310, 2989, $1735,1712,1596,1486,1264 \mathrm{~cm}^{-1}$; MS (EI) $\mathrm{m} / z(\%): 256$ (8), $141(33), 139(100), 111(14)$.

Diisopropyl

1-(1-naphthoyl)hydrazine-1,2dicarboxylate (3k): White solid; $\mathrm{mp}=102-104{ }^{\circ} \mathrm{C}$ (hexane); $\mathrm{t}_{\mathrm{r}}=19.0 ; \mathrm{R}_{\mathrm{f}}=0.4$ (hexane/ethyl acetate: $3 / 2$ ); ${ }^{1} \mathrm{H}$ NMR (300 MHz, CDCl $\left.)_{3}\right): \delta 8.15-8.2(\mathrm{~m}, 1 \mathrm{H}), 7.93(\mathrm{~d}, J=$ $7.9 \mathrm{~Hz}, 1 \mathrm{H}), 7.86(\mathrm{~d}, J=7.9 \mathrm{~Hz}, 1 \mathrm{H}), 7.6-7.65(\mathrm{~m}, 1 \mathrm{H})$ 7.45-7.55 (m, 3H), 7.1 (s, 1H), 5.05-5.1 (m, 1H), 4.65-4.7 $(\mathrm{m}, 1 \mathrm{H}), 1.34(\mathrm{~d}, J=6.2 \mathrm{~Hz}, 6 \mathrm{H}), 0.65-0.75(\mathrm{~m}, 6 \mathrm{H}) ;{ }^{13} \mathrm{C}$ NMR $\left(75 \mathrm{MHz} \mathrm{CDCl}_{3}\right): \delta 170.4,155.3,152.0,134.1$ $133.1,130.5,129.9,128.2,127.3,126.4,124.7,124.6(2 \mathrm{C})$, 72.3, 70.7, 21.9 (2C), 20.8 (2C); IR (ATR): v 3278, 1760 , 1743, 1514, $1251 \mathrm{~cm}^{-1}$; MS (EI) $\mathrm{m} / z(\%): 358\left(\mathrm{M}^{+}, 6\right), 156$ (26), 155 (100), 127 (61); Elemental analysis calcd. for $\mathrm{C}_{19} \mathrm{H}_{22} \mathrm{~N}_{2} \mathrm{O}_{5}: \mathrm{C}=63.67, \mathrm{H}=6.19, \mathrm{~N}=7.82$; found: $\mathrm{C}=$ $63.8, \mathrm{H}=6.25, \mathrm{~N}=7.9$.

Diisopropyl 1-(thiophene-2-carbonyl)hydrazine-1,2dicarboxylate $(3 \mathrm{l}):{ }^{[1]}$ Colorless oil; $\mathrm{t}_{\mathrm{r}}=16.0 ; \mathrm{R}_{\mathrm{f}}=0.47$ (hexane/ethyl acetate: $3 / 2) ;{ }^{1} \mathrm{H}$ NMR $\left(300 \mathrm{MHz}, \mathrm{CDCl}_{3}\right): \delta$ $7.89(\mathrm{dd}, J=3.9 \mathrm{~Hz}, J=1.3 \mathrm{~Hz}, 1 \mathrm{H}), 7.6(\mathrm{dd}, J=5.0 \mathrm{~Hz}, J$ $=1.3 \mathrm{~Hz}, 1 \mathrm{H}), 7.22(\mathrm{~s}, \mathrm{br}, 1 \mathrm{H}), 7.09(\mathrm{dd}, J=5.0 \mathrm{~Hz}, J=$ $3.9 \mathrm{~Hz}, 1 \mathrm{H}), 4.95-5.1(\mathrm{~m}, 2 \mathrm{H}), 1.25-1.35(\mathrm{~m}, 12 \mathrm{H}) ;{ }^{13} \mathrm{C}$ NMR (75 MHz, $\left.\mathrm{CDCl}_{3}\right): \delta 162.6,155.3,154.8,152.6$, $135.5,133.5,127.1,72.6,70.8,21.8$ (2C), 21.5 (2C); IR (ATR): $v$ 3299, 1736, $1234 \mathrm{~cm}^{-1}$; MS (EI) $\mathrm{m} / z$ (\%): 228 (12), $186(8), 142(10), 111$ (100).

Diisopropyl 1-cinnamoylhydrazine-1,2-dicarboxylate $(3 \mathrm{~m}):{ }^{17}$ Colorless oil; $\mathrm{t}_{\mathrm{r}}=17.9 ; \mathrm{R}_{\mathrm{f}}=0.53$ (hexane/ethyl acetate: $3 / 2) ;{ }^{1} \mathrm{H}$ NMR $\left(300 \mathrm{MHz}, \mathrm{CDCl}_{3}\right): \delta 7.72(\mathrm{~d}, J=$ $15.7 \mathrm{~Hz}, 1 \mathrm{H}), 7.45-7.5(\mathrm{~m}, 3 \mathrm{H}), 7.25-7.3(\mathrm{~m}, 3 \mathrm{H}), 6.81(\mathrm{~s}$ br, $1 \mathrm{H}$ ), 5.01 (heptet, $J=6.3 \mathrm{~Hz}, 1 \mathrm{H}$ ), 4.93 (heptet, $J=6.3$ $\mathrm{Hz}, 1 \mathrm{H}), 1.27(\mathrm{~d}, J=6.3 \mathrm{~Hz}, 6 \mathrm{H}), 1.15-1.25(\mathrm{~m}, 6 \mathrm{H}) ;{ }^{13} \mathrm{C}$ NMR (75 MHz, $\left.\mathrm{CDCl}_{3}\right): \delta 166.5,155.1,152.8,145.8$ 134.6, 130.4, 128.4 (2C), 118.8, 72.3, 70.4, 21.8 (2C), 21.7 (2C); IR (ATR): $v$ 3311, 1732, $1236 \mathrm{~cm}^{-1}$; MS (EI) $\mathrm{m} / \mathrm{z}$ (\%): 132 (10), 131 (100), 103 (16).

Diisopropyl 1-butyrylhydrazine-1,2-dicarboxylate (3n): ${ }^{[8 b]}$ Colorless oil; $\mathrm{t}_{\mathrm{r}}=13.01 ; \mathrm{R}_{\mathrm{f}}=0.6$ (hexane/ethyl acetate: $3 / 2) ;{ }^{1} \mathrm{H}$ NMR $\left(300 \mathrm{MHz}, \mathrm{CDCl}_{3}\right): \delta 6.84(\mathrm{~s}, \mathrm{br}$, $1 \mathrm{H}), 4.85-5.0(\mathrm{~m}, 2 \mathrm{H}), 2.80-2.85(\mathrm{~m}, 2 \mathrm{H}), 1.62(\mathrm{~m}, 2 \mathrm{H})$, $1.2-1.25(\mathrm{~m}, 12 \mathrm{H}), 0.9(\mathrm{t}, J=7.4 \mathrm{~Hz}, 3 \mathrm{H}) ;{ }^{3} \mathrm{C}$ NMR $(75$ $\left.\mathrm{MHz}, \mathrm{CDCl}_{3}\right): \delta 173.7,155.1,152.6,71.9,70.2,38.7,21.8$ (2C), 21.6 (2C), 18.0, 13.5; IR (ATR): v 3311, 1719, 1235 $\mathrm{cm}^{-1}$; MS (EI) m/z (\%): 204 (48), 173 (10), 162 (28), 146 (13), 120 (33), 118 (46), 103 (13), 102 (20), 76 (51), 71 (100), 59 (11).
Diisopropyl 1-nonanoylhydrazine-1,2-dicarboxylate (3o): ${ }^{\text {ta }}$ Colorless oil; $\mathrm{t}_{\mathrm{r}}=16.2 . \mathrm{R}_{\mathrm{f}}=0.7$ (hexane/ethyl acetate:3/2); ${ }^{1} \mathrm{H}$ NMR $\left(300 \mathrm{MHz}, \mathrm{CDCl}_{3}\right): \delta 6.66(\mathrm{~s}, \mathrm{br}$, $1 \mathrm{H}), 4.9-5.1(\mathrm{~m}, 2 \mathrm{H}), 2.85-2.9(\mathrm{~m}, 2 \mathrm{H}), 2.85-2.9(\mathrm{~m}, 2 \mathrm{H})$, $1.6-1.7(\mathrm{~m}, 2 \mathrm{H}), 1.2-1.35(\mathrm{~m}, 22 \mathrm{H}), 0.87(\mathrm{t}, J=6.7 \mathrm{~Hz}$, $3 \mathrm{H}) ;{ }^{13} \mathrm{C}$ NMR $\left(75 \mathrm{MHz}, \mathrm{CDCl}_{3}\right): \delta 173.9,155.1,152.6$, $71.9,70.2,36.9,31.7,29.2,29.0$ (2C), 24.6, 22.5, 21.8 (2C), 21.6 (2C), 14.0; IR (ATR): v 3314, 2981, 2925, 1720, $1244 \mathrm{~cm}^{-1}$; MS (EI) m/z (\%): 205 (12), 204 (100), 162 (44), 160 (12), 141 (52), 120 (24), 118 (70), 76 (32), 71 (26), 57 (28), 55 (13).

\begin{abstract}
Diisopropyl 1-(2-ethylbutanoyl)hydrazine-1,2dicarboxylate (3p): Colorless oil; $\mathrm{t}_{\mathrm{r}}=13.6 ; \mathrm{R}_{\mathrm{f}}=0.73$ (hexane/ethyl acetate: $3 / 2) ;{ }^{1} \mathrm{H} \mathrm{NMR}\left(300 \mathrm{MHz}, \mathrm{CDCl}_{3}\right): \delta$ $7.01(\mathrm{~s}, \mathrm{br}, 1 \mathrm{H}), 4.95-5.1(2 \mathrm{~m}, 1$ and $1 \mathrm{H}$, respectively), $3.45-3.5(\mathrm{~m}, 1 \mathrm{H}), 1.65-1.8(\mathrm{~m}, 2 \mathrm{H}), 1.5-1.6(\mathrm{~m}, 2 \mathrm{H}), 1.32$ $(\mathrm{d}, J=6.3 \mathrm{~Hz}, 6 \mathrm{H}), 1.25-1.3(\mathrm{~m}, 6 \mathrm{H}), 0.91(\mathrm{t}, J=7.4 \mathrm{~Hz}$, $6 \mathrm{H}) ;{ }^{13} \mathrm{C} \mathrm{NMR}\left(75 \mathrm{MHz}, \mathrm{CDCl}_{3}\right): \delta 177.0,155.1,152.6$, $71.8,70.0,47.3,24.7$ (2C), 21.7 (2C), 21.5 (2C) 11.4 (2C); IR (ATR): $v 3311,2970,2937,2878,1719,1230 \mathrm{~cm}^{-}$ ; MS (EI) $m / z(\%): 302\left(\mathrm{M}^{+},<0.1 \%\right), 204$ (16), 162 (9), 120 (15), 99 (46), 98 (22), 76 (11), 71 (100); Elemental analysis calcd. for $\mathrm{C}_{14} \mathrm{H}_{26} \mathrm{~N}_{2} \mathrm{O}_{5}: \mathrm{C}=55.61, \mathrm{H}=8.67, \mathrm{~N}=$ 9.26; found: $\mathrm{C}=55.57, \mathrm{H}=8.60, \mathrm{~N}=9.19$.
\end{abstract}

Diisopropyl 1-pivaloylhydrazine-1,2-dicarboxylate (3q) ${ }^{[8 b]}$ Colorless oil; $t_{\mathrm{r}}=12.7 ; \mathrm{R}_{\mathrm{f}}=0.73$ (hexane/ethyl acetate: $3 / 2) ;{ }^{1} \mathrm{H}$ NMR (300 MHz, $\left.\mathrm{CDCl}_{3}\right)$ : $\delta 6.81$ (s, br, $1 \mathrm{H}), 4.95-5.1(\mathrm{~m}, 2 \mathrm{H}), 1.2-1.35(\mathrm{~m}, 21 \mathrm{H}) ;{ }^{13} \mathrm{C}$ NMR $(75$ $\left.\mathrm{MHz}, \mathrm{CDCl}_{3}\right): \delta 179.6,155.7,153.2,72.1,70.5,42.0,27.4$ (2C), 21.8 (2C), 21.6 (2C); IR (ATR): v 3295, 2981, 1720, $1227 \mathrm{~cm}^{-1}$; MS (EI) $\mathrm{m} / \mathrm{z}(\%): 204$ (37), 162 (30), 120 (43), 118 (15), 103 (11), 85 817), 76 (31), 57 (100).

(Z)-Diisopropyl 1-(dec-7-enoyl)hydrazine-1,2dicarboxylate $(3 \mathbf{r})$ : Colorless oil; $\mathrm{t}_{\mathrm{r}}=16.7 ; \mathrm{R}_{\mathrm{f}}=0.47$ (hexane/ethyl acetate: 4/1); $\mathrm{H}$ NMR (300 MHz, $\left.\mathrm{CDCl}_{3}\right): \delta$ $6.72(\mathrm{~s}, \mathrm{br}, 1 \mathrm{H}), 4.90-5.1(\mathrm{~m}, 2 \mathrm{H}), 2.90(\mathrm{t}, J=6.8 \mathrm{~Hz}, 2 \mathrm{H})$, $1.95-2.05(\mathrm{~m}, 4 \mathrm{H}), 1.6-1.7(\mathrm{~m}, 2 \mathrm{H}), 1.2-1.4(\mathrm{~m}, 16 \mathrm{H}), 0.95$ $(\mathrm{t}, J=7.5 \mathrm{~Hz}, 3 \mathrm{H}) ;{ }^{13} \mathrm{C}$ NMR $\left(75 \mathrm{MHz}, \mathrm{CDCl}_{3}\right): \delta 173.0$, $155.1,152.6,131.7,128.9,72.0,70.3,36.9,29.4,28.7$, $26.9,24.5,21.8$ (2C), 21.6'(2C), 20.4, 14.3; IR (ATR): $v$ $3313,1736,1502,1237 \mathrm{~cm}^{-1}$; MS (EI) $\mathrm{m} / z(\%): 356\left(\mathrm{M}^{+}\right.$, $0.08), 205$ (14), 204 (100), 163 (11), 162 (49), 153 (54), 152 (32), 135 (13), 123 816), 121 (13), 120 (27), 118 (74), 109 (11), 83 (15), 76 (43), 71 (10), 69 (37), 67 (16), 55 (31); Elemental analysis calcd. for $\mathrm{C}_{18} \mathrm{H}_{32} \mathrm{~N}_{2} \mathrm{O}_{5}$ : $\mathrm{C}=60.65$, $\mathrm{H}=9.05, \mathrm{~N}=7.86$; found: $\mathrm{C}=60.67, \mathrm{H}=9.03, \mathrm{~N}=7.87$.

Diethyl 1-benzoylhydrazine-1,2-dicarboxylate $(3 \mathrm{~s})::^{[18]}$ Colorless oil; $\mathrm{t}_{\mathrm{r}}=15.5 ; \mathrm{R}_{\mathrm{f}}=0.5$ (hexane/ethyl acetate: $3 / 2$ ); ${ }^{1} \mathrm{H}$ NMR $\left(300 \mathrm{MHz}, \mathrm{CDCl}_{3}\right): \delta 7.68(\mathrm{~d}, J=7.1 \mathrm{~Hz}, 2 \mathrm{H})$, $7.35-7.55(\mathrm{~m}, 3 \mathrm{H}), 7.24(\mathrm{~s}, \mathrm{br}, 1 \mathrm{H}), 4.25$ (q, $J=7.1 \mathrm{~Hz}$, $2 \mathrm{H}), 4.15(\mathrm{q}, J=7.1 \mathrm{~Hz}, 2 \mathrm{H}), 1.29(\mathrm{t}, J=7.1 \mathrm{~Hz}, 3 \mathrm{H}), 1.07$ $(\mathrm{t}, J=7.1 \mathrm{~Hz}, 3 \mathrm{H}) ;{ }^{13} \mathrm{C}$ NMR $\left(75 \mathrm{MHz}, \mathrm{CDCl}_{3}\right): \delta 172.1$, $155.7,153.4,133.7,132.0,130.1,128.4,128.1,64.0$ (2C), 14.3 (2C); IR (ATR): v 3312, 2921, 1705, $1222 \mathrm{~cm}^{-1}$; MS (EI) $\mathrm{m} / \mathrm{z}(\%): 106(8), 105(100), 77(21)$.

Di-tert-butyl 1-benzoylhydrazine-1,2-dicarboxylate (3t): White solid; $\mathrm{mp}=118-120{ }^{\circ} \mathrm{C}$ (hexane); $\mathrm{t}_{\mathrm{r}}=14.9 ; \mathrm{R}_{\mathrm{f}}=0.67$ (hexane/ethyl acetate: $3 / 2) ;{ }^{1} \mathrm{H}$ NMR $\left(300 \mathrm{MHz}, \mathrm{CDCl}_{3}\right): \delta$ $8.15-8.2(\mathrm{~m}, 1 \mathrm{H}), 7.93(\mathrm{~d}, J=7.9 \mathrm{~Hz}, 1 \mathrm{H}), 7.71(\mathrm{~d}, J=7.7$ $\mathrm{Hz}, 2 \mathrm{H}), 7.51(\mathrm{t}, J=7.4 \mathrm{~Hz}, 2 \mathrm{H}), 7.42(\mathrm{t}, J=7.4 \mathrm{~Hz}, 2 \mathrm{H})$, $6.84(\mathrm{~s}, \mathrm{br}, 1 \mathrm{H}), 1.50(\mathrm{~s}, 9 \mathrm{H}), 1.23(\mathrm{~s}, 9 \mathrm{H}) ;{ }^{13} \mathrm{C}$ NMR $(75$ $\left.\mathrm{MHz}, \mathrm{CDCl}_{3}\right): \delta$ 171.6, 154.5, 151.7, 135.8, 131.7, 128.1 (4C), 84.4, 82.2, 28.1 (3C), 27.4 (3C); IR (ATR): v 3336, 1760, 1721, 1703, 1280, $1063 \mathrm{~cm}^{-1}$; MS (EI) $\mathrm{m} / \mathrm{z}(\%): 180$ (13), 163 (22), 136 (37), 105 (100), 77 (47), 59 810), 57 894), 51 (15); Elemental analysis calcd. for $\mathrm{C}_{17} \mathrm{H}_{24} \mathrm{~N}_{2} \mathrm{O}_{5}$ : C $=60.7, \mathrm{H}=7.19, \mathrm{~N}=8.33$; found: $\mathrm{C}=60.65, \mathrm{H}=7.23, \mathrm{~N}$ $=8.32$.

\section{Acknowledgements}


This work was supported by the Spanish Ministerio de Economia y Competitividad (MICINN; CTQ2011-24151) and University of Alicante. J.M.P. thanks the MICINN (FPI program) for her fellowship. We gratefully acknowledge the polishing of our English by Mrs. Oriana C. Townley.

\section{References}

[1] a) O. Mitsunobu in Comprehensive Organic Synthesis Vol 6 (Eds. B. M. Trost), Pergamon Press, Oxford, 1991, 65-101; b) O. Mitsunobu in Comprehensive Organic Synthesis Vol 6 (Eds. B. M. Trost), Pergamon Press, Oxford, 1991, pp 381-411; c) C. M. Manson, A. D. Hobson in Comprehensive Organic Functional Group Transformations Vol 2 (Eds. A. R. Katritzky, O. Meth-Cohn, C. W. Rees), Pergamon, Cambridge, 1995, pp 297-332; d) P. D. Bailey, I. D. Collier, K. M. Morgan in Comprehensive Organic Functional Group Transformations Vol 5 (Eds. A. R. Katritzky, O. MethCohn, C. W. Rees), Pergamon, Cambridge, 1995, pp 257-307.

[2] See for instance: a) J. F. Hartwig, Science 2002, 297, 1653; b) M. Beller, J. Seayad, A. Tillack, H. Jiao, Angew. Chem. Int. Ed. 2004, 43, 3368-3398; c) V. Nair, R. S. Menon, A. R. Sreekanth, N. Abhilash, A. T. Biju, Acc. Chem. Res. 2006, 39, 520-530; d) R. Matsubara, S. Kobayashi, Acc. Chem. Res. 2008, 41, 292-301.

[3] V. Nair, A. T. Mathew, B. P. Babu, Chem. Asian J. 2008, 38, 810-820.

[4] a) C. González-Rodríguez, M. C. Willis, Pure Appl. Chem. 2011, 83, 577-585; b) P. W. N. M. van Leeuwen in Science of Synthesis: Stereoselective Synthesis Vol. 1 (Eds.: J. G. de Vries), Thieme, Stuttgart, 2011, pp 409-475; c) S. Bräse, Nachr. Chem. 2012, 60, 265-299; d) J. C. Leung, M. J. Krische, Chem. Sci. 2012, 3, 2202-2209.

[5] O. Diels, E. Fisher, Ber. Dtsch. Chem. Ges. 1914, 47, 2043-2047.

[6] a) K. Alder, T. Noble, Ber. Dtsch. Chem. Ges. 1943, 76B, 54-57; b) R. Huisgen, F. Jakob, Justus Liebigs Ann. Chem. 1954, 590, 37-54; c) G. O. Schenck, H. Formaneck, Angew. Chem. 1958, 70, 505; d) M. E. González-Rosende, O. Lozano-Lucia, E. ZaballosGarcía, J. Sepúlveda-Arques, J. Chem. Res., Synop 1995, 260-261; e) E. Zaballos-García, M. E. GonzálezRosende, J. M. Jorda-Gregori, J. Sepúlveda-Arques, Tetrahedron 1997, 53, 9313-9322.

[7] B. Ni,Q. Zhang, S. Garre, A. D. Headley, Adv. Synth. Catal. 2009, 351, 875-880.

[8] a) Q. Zhang, E. Parker, A. D. Headley, B. Ni, Synlett 2010, 2453-2456; b) V. Chudasama, J. M. Ahern, D. V. Dhokia, R. J. Fitzmaurize, S. Caddick, Chem. Commun. 2011, 47, 3269-3271; c) V. Chudasama, A. R. Akhbar,
K. A. Bahou, R. J. Fitzmaurice, S. Caddick, Org. Biomol. Chem. 2013, 11, 7301-7317.

[9] a) D. Lee, R. D. Otte, J. Org. Chem. 2004, 69, 35693571; b) Y. J. Kim, D. Lee, Org. Lett. 2004, 6, 43514353.

[10] Y. Qin, Q. Peng, J. Song, D. Zhou, Tetrahedron Lett. 2011, 52, 5880-5883.

[11] Y. Qin, D. Zhou, M. Li, Lett. Org. Chem. 2012, 9, 1875-1786.

[12] S. M. Inamdar, V. K. More, S. K. Mandal, Chem. Lett. 2012, 41, 1484-1486.

[13] a) M. J. Aliaga, D. J. Ramón, M. Yus, Org. Biomol. Chem. 2010, 8, 43-46; b) R. Cano, D. J. Ramón, M. Yus, J. Org. Chem. 2010, 75, 3458-3460; c) R. Cano, D. J. Ramón, M. Yus, Tetrahedron 2011, 67, 54325436; d) R. Cano, D. J. Ramón, M. Yus, J. Org. Chem. 2011, 76, 5547-5557; e) R. Cano, M. Yus, D. J. Ramón, Tetrahedron 2011, 67, 8079-8085; f) R. Cano, D. J. Ramón, M. Yus, Tetrahedron 2012, 68, 1393-1400; g) R. Cano, M. Yus, D. J. Ramón, ACS Catal. 2012, 2, 1070-1078; h) R. Cano, M. Yus, D. J. Ramón, Chem. Commun. 2012, 48, 7628-7630; i) J. M. Pérez, R. Cano, M. Yus, D. J. Ramón, Eur. J. Org. Chem. 2012, 45484554; j) J. M. Pérez, R. Cano, M. Yus, D. J. Ramón, Synthesis 2013, 1373-1379; k) R. Cano, J. M. Pérez, D. J. Ramón, Appl. Catal. A-Gen. 2014, 470, 177-182.

[14] a) S. Roy, M. A. Pericàs, Org. Biomol. Chem. 2009, 7, 2669-2677; b) A. Schätz, O. Reiser, W. J. Stark, Chem. Eur. J. 2010, 16, 8950-8967; c) V. Polshettiwar, R. S. Varma, Green Chem. 2010, 12, 743-754; d) S. Shylesh, V. Schünemann, W. R. Thiel, Angew. Chem. Int. Ed. 2010, 49, 3428-3459; e) K. V. S. Ranganth, F. Glorius, Catal. Sci. Technol. 2011, 1, 13-22. f) V. Polshettiwar, R. Luque, A. Fihri, H. Zhu, M. Bouhrara, J. -M. Basset, Chem. Rev. 2011, 111, 3036-3075. g) M. B. Gawande, P. S. Branco, R. S. Varma, Chem. Soc. Rev. 2013, 42, 3371-3393; h) R. B. N. Baig, R. S. Varma, Chem. Commun. 2013, 49, 752-770.

[15] M. B. Gawande, A. Rathi, I. D. Nogueira, C. A. A. Ghumman, N. Bundaleski, O. M. N. D. Teodoro, P. S. Branco, ChemPlusChem 2012, 77, 865-871.

[16] For the XPS data of other metal-impregnated magnetite catalysts, see: R. Cano, PhD Dissertation, Univ. Alicante, 2013 (http://rua.ua.es/dspace/bitstream/10045/30276/1/tesis_ rafael_cano.pdf).

[17] Y. Quin, Q. Peng, J. Song, D. Zhou, Tetrahedron Lett. 2011, 52(44), 5880-5883.

[18] T. Osikawa, M. Yamashita, Rep. Fac. Eng. Shizuoka Univ. 1984, 35, 37-40. 


\section{FULL PAPER}

Cobalt-Impregnated Magnetite as General

Heterogeneous Catalyst for the Hydroacylation

Reaction of Azodicarboxylates

Adv. Synth. Catal. Year, Volume, Page - Page

Juana M. Pérez, Diego J. Ramón*

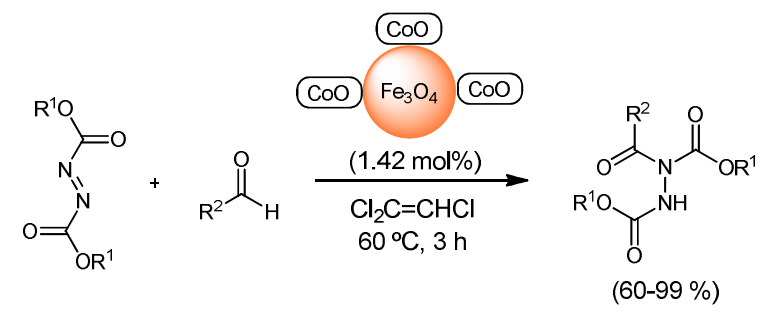

